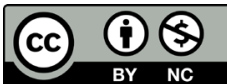

Licenciado sob uma licença Creative Commons

ISSN 2175-6058

DOI: http://dx.doi.org/10.18759/rdgf.v20i3.1776

\title{
A ABORDAGEM DA DIFERENÇA COMO CATEGORIA CRÍTICA DA IGUALDADE MODERNA NA LITERATURA DE EDUARDO GALEANO
}

THE APPROACH TO DIFFERENCE AS A CRITICAL CATEGORY OF MODERN EQUALITY IN EDUARDO GALEANO'S LITERATURE

Doglas Cesar Lucas

André Leonardo Copetti Santos

\section{RESUMO}

Este trabalho estuda a literatura de Eduardo Galeano, buscando nela identificar elementos crítico-políticos da ideia de igualdade pela presença da categoria conceitual da diferença. Partindo da metodologia fenomenológica, objetiva-se desvelar o potencial epistemológico da obra de Galeano, permitindo analisar criticamente categorias próprias do Direito, como a igualdade. Os resultados da pesquisa indicam que na obra de Galeano há nítidos elementos do que hoje se chama epistemologias do sul político global, os quais encerram ligações muito estreitas com as críticas sobre a igualdade formal da modernidade, especialmente pela consideração da diferença como categoria central à compreensão da complexidade do mundo contemporâneo.

Palavras-chave: Diferença. Eduardo Galeano. Epistemologias do Sul. 


\section{ABSTRACT}

This paper studies the literature of Eduardo Galeano, seeking to identify criticalpolitical elements of the idea of equality through the presence of the conceptual category of difference. Starting from the phenomenological methodology, the objective is to unveil the epistemological potential of Galeano's literary work, allowing a critical analysis of the proper categories of law, such as equality. The results of the research indicate that in Galeano's work there are clear elements of what is today called the epistemologies of the global political south, which have very close links with critiques of the formal equality of modernity, especially by considering difference as a central category to understanding of the complexity of the contemporary world.

Keywords: Difference. Eduardo Galeano Epistemologies of the South.

\section{INTRODUÇÃO}

A modernidade inaugurou um processo de hipercientificização das propostas políticas e jurídicas de emancipação, tornando possível a elaboração de promessas bastante ambiciosas, notadamente de quatro grandes promessas: a promessa da igualdade, a da liberdade, a da paz e a da conquista da natureza (SANTOS, 2009). Uma das consequências desse processo foi a substituição de uma ordem transcendental de compreensão do mundo por arranjos racionais. Intencionava-se, com isso, substituir um mito por outro, o antigo Deus católico por um novo Deus, a Deusa Razão. As promessas dessa Deusa não só não se cumpriram nos termos em que nos haviam sido entregues, como a ciência moderna, em lugar de eliminar os excessos e as insuficiências, as potencializou e as modulou a partir de seus próprios termos. Nos dias atuais, a falência dessas promessas é mais que evidente. Os níveis de desigualdade são apavorantes, a falta de liberdade escancara as limitações de muitos projetos de sociedade, um sem número de conflitos abatem vidas impiedosamente e o domínio da natureza atingiu o seu clímax, não mais como domínio, mas como destruição.

A resposta aos excessos da razão veio através do crescimento cada vez mais acelerado de movimentos de retorno ao transcendental mítico 
religioso, mas também pela elaboração de alternativas contemporâneas de acolhimento, entorpecimento e tratamento de subjetividades atormentadas. Sujeitos atomizados e em desespero apelam novamente para os céus e para as soluções terapêuticas que sejam capazes de garantir, simbolicamente, um pouco de certeza e segurança. Particularmente neste momento da história da humanidade os discursos religiosos reocupam, por novas narrativas, um lugar bastante destacado; os novos fundamentalismos são cada vez mais potentes e constroem estatutos, práticas e discursos muito efetivos na sociedade contemporânea. E nesses discursos, a figura do Diabo condensa uma espécie de unidade de sentimento contra o diferente, contra o estranho, que alimenta uma concepção de "nós" contra "eles", os de "dentro" contra os de "fora".

No presente trabalho, buscando explorar um diálogo entre religião e literatura e entre literatura e Direito, intenta-se estabelecer uma conexão entre os discursos religioso e literário sobre o Diabo, construído como o diferente minoritário. Utiliza-se como referencial literário as obras "Espelhos: uma história quase universal", de Eduardo Galeano, na qual o autor uruguaio elenca nove formas de personificação coletiva do Diabo. Também nos apoiamos nas obras "O livro dos abraços", "Mulheres" e "Os filhos dos dias", do mesmo escritor.

O objetivo deste texto é demonstrar o potencial epistemológico do trabalho literário de Galeano e, portanto, sua importância como modelo de conhecimento específico a ser obtido a partir de textos ficcionais, com projeção do seu conteúdo para a análise e crítica de categorias próprias às ciências humanas, e mais especificamente com uma vinculação estreita com o Direito. Em termos mais específicos, a análise do texto de Galeano buscou desmistificar uma das principais santas seguidoras da Deusa moderna conhecida como Razão, a Santa Igualdade, além de, como contraponto, propor suas escrituras como ferramentas de análise e reinterpretação da categoria da diferença, mais adequada à compreensão da complexidade do mundo atual.

Para o desenvolvimento dessa empreitada teórica, utilizamos o método fenomenológico a fim de deixar e fazer ver a os elementos literários na obra de Eduardo Galeano que destacam a diferença por si mesma, tal como se mostra a partir de si mesma, de modo que permita 
a ela demonstrar-se diretamente, com conceitos, através de processos que contêm um componente aconceitual, e não a partir de postulados de outros fenômenos ou de doutrinas tradicionais. A proposta de trabalho busca não a abordagem da diferença em particular, mas aspectos do seu ser, aspectos que embora se mostrem de forma implícita e "nãotematizada", podem chegar a mostrar-se tematicamente.

\section{SOBRE A RELAÇÃO ENTRE DIREITO E LITERATURA E SUA POTENCIALIDADE CRÍTICA}

Os acoplamentos entre distintos campos do saber não é algo novo. A filosofia, mãe de todas as ciências, era, em seus primórdios, um grande aglomerado de conhecimentos de distinto caráter, agrupados sob uma mesma denominação. As relações entre natureza e cultura não eram tão distinguidas como passaram a ser na modernidade, e, por consequência, as relações ou interseções entre ramos do conhecimento mais dedicados à natureza ou à cultura não eram tão relevantes assim. Com a especificação, na modernidade, de áreas do conhecimento com uma intensidade jamais vista na história da humanidade - processo que em sua maior medida deve ser atribuído ao racionalismo -, o desfazimento do grande pacote de conhecimentos chamado filosofia levou a um constante afastamento das ciências umas das outras e de todas em relação à filosofia, situação que induziu e guiou cientistas a cada vez mais desejarem a pureza, a autonomia de suas construções teóricas. No campo específico do direito esse movimento é bastante evidente.

Mas se na modernidade ocorreu este isolamento entre as distintas ciências e delas em relação à filosofia, por outro lado, foi, nesta mesma época, no campo da reflexão teórica que se passou a reconstruir pontes parciais entre as ciências e entre elas e a filosofia. Nas possibilidades e necessidades de imbricação próprias ao direito, observa-se a ligação, para exemplificar, do direito com a economia, com a psicologia, com a ciência política, com a sociologia, com a antropologia etc. No século XX, materializou-se, de forma mais intensa, uma aproximação entre direito e arte que, como já mencionado, não era propriamente inédita. Essa 
ligação entre direito e arte é mais palpável em relação à literatura, mas em hipótese alguma pode ser descartada referentemente em relação a outras manifestações artísticas como, por exemplo, entre direito e artes pictóricas, direito e cinema e direito e música.

Mais detidamente quanto ao objeto do presente trabalho, que relaciona direito com literatura, pode-se apontar uma série de elementos que tornam possível a convergência desses dois campos culturais. Utilizase aqui uma relação de fatores que Rotman de Miranda (2010) relaciona como essenciais para a aproximação entre filosofia e arte, mas que, sem dúvida alguma, são também adequados para entender as possibilidades de acercamento entre direito e arte: ambos são expressões superiores do espírito humano; também são o resultado de um determinado momento histórico; tanto um quanto o outro são o resultado da confluência de: crenças, ideologias, valores, organização sociopolítica, economia, ciência e técnica; arte e direito emergem de representações mentais e usam linguagem; uma e outra são expressões de um universo simbólico e requerem interpretação; desenvolvem a sensibilidade e aguçam o intelecto; requerem um ato profundo de pensamento; são disparadores para a compreensão da realidade que os produziu; revestem-se do pensamento filosófico próprio de sua época; e, por fim, são acessíveis aos seres humanos por sua condição de humanidade.

Em termos históricos, as origens do Law as Literature remetem a John Henry Wigmore, jurista norte-americano, a partir da publicação de sua A List of Legal Novels, em 1908. Posteriormente, no ano 1925, Benjamin Cardozo, juiz da Suprema Corte norte-americana, buscou trazer a forma da literatura para o direito, isto é, a possibilidade de textos jurídicos serem interpretados e lidos como textos literários (TRINDADE; BERNSTS, 2017). Por fim, surge, em 1970, o Law and Literature Movement, ou Law and Literature Scholarship, ou, ainda, Law and Literature Enterprise, movimento que estuda o Direito pela Literatura, examinando, assim, a qualidade literária do Direito. Esse debate promovido pelo Law and Literature Movement contou com a participação de pensadores como James Boyd White (1985), Richard Weisberg (1979 e 1988), Robert Weisberg e Guyora Binder (2000) Richard Posner (1986, 1990 e 2007), Jerome Bruner 2014), Sanford Levinson (2020), Martha Nussbaum 
(1997) Stanley Fish (1987) e Owen Fiss 1982), dentre outros (TRINDADE; BERNSTS, 2017).

Dentro das possibiliades de se estabelecer relações entre esses ramos culturais, há várias tentativas de se ordenar direito e literatura. Thomas Morawetz (2007) indica, em primeiro lugar, que o direito $n a$ literatura se estende à descrição de advogados e de instituições jurídicas nos textos literários. Advogados desfilam como heróis, anti-heróis, vilões. É o que se encontra nos textos de de Dickens (Bleak House), Kafka (O Processo), Shakespeare (O Mercador de Veneza), Sófocles (Antígona), Coetzee (À Espera dos Bárbaros). Tenta-se encontrar o jurídico no literário, explícita e subliminarmente. Morawetz também nos dá conta da compreensão do direito como literatura, onde se investiga o conjunto de transmissão de significados, no espaço jurídico, marcado pelo autoritarismo e pelas injunções políticas. 0 mesmo autor ainda aponta um terceiro campo: a literatura como instrumento e fator para a reforma do direito. Tenta-se verificar como a literatura popular poderia influenciar movimentos para mudança da legislação e das práticas judiciárias. Orienta-se para uma literatura politicamente inspirada. Os efeitos sociolegais da literatura são o principal objeto de investigação.

Assim como as interseções epistemológicas entre o direito e outros campos do saber lhe acrescentam distintas perspectivas, sejam de partida ou chegada, as possibilidades e os horizontes da relação entre direito e arte são também inúmeros. De acordo com Morawetz (2007), entre estes horizontes podemos encontrar o direito na literatura e a literatura no direito; o direito da literatura e a literatura como padrão e impulso para reforma do direito; assim como a combinação entre direito e ficção na busca de referenciais éticos. Ost (2004) identifica vários campos de interação entre o Direito e a Literatura: o Direito da Literatura, o Direito como Literatura, o Direito na Literatura e o Direito pela Literatura. A literatura, diz o autor, não oferece respostas técnicas, mas abona dois imaginários que, ao seu modo, acessam a narrativa dos costumes de uma comunidade. A lei obriga, de forma narrada, determinadas práticas para uma sociedade. A literatura, por sua vez, reproduz os sentidos das regras, questiona sua legitimidade e inventa seu próprio itinerário. Justamente por isso a literatura pode antecipar a crítica, sugerir mudanças e contar, a 
seu modo, a lei. Enquanto a literatura liberta os possíveis, duvida, critica, propõe outras alternativas, é inventiva, o direito codifica e encerra a realidade, dirá Ost. 0 direito não é literatura, mas revela-se e questiona-se nela. A literatura não é direito, mas faz dele o seu objeto de prospecção e interrogação permanente. Dworkin (2001), por seu turno, ao tratar do processo interpretativo, sugere uma compreensão do direito como literatura. Para garantir a integridade e coerência do direito, o juiz deve interpretar respeitando as narrativas do passado, para saber o que foi dito e construído coletivamente. 0 direito se apresenta com uma estrutura que só pode ser compreendida e interpretada se o jurista não sonegar o processo histórico de sua elaboração e a atribuição coletiva de sentidos. A integridade e coerência dessa narrativa exige compreender as narrativas e enredos que vêm antes. Tal qual num romance escrito em cadeia, elaborado por muitas mãos em tempos distintos, cada um dos novos autores deverá se apropriar do que já foi narrado e interpretar as palavras de seus companheiros, garantindo, com isso, a coerência da estória.

No Brasil, o movimento de fusão entre direito e arte, especialmente direito e literatura, com uma função absolutamente crítica da dogmática jurídica, é iniciado com Warat (1985), através das metáforas literárias presentes no livro Ciência Jurídica e seus Dois Maridos. A obra busca um deslocamento do mundo confortável da estabilidade e da segurança jurídica para outras direções distantes da dogmática castradora, com o intuito de abrir-se às múltiplas armadilhas da narrativa científica jurídica, a qual comporta nossas próprias armadilhas. Nesse livro, Warat, pelo uso da literatura como chave de compreensão crítica do direito, estimula a sensação de desconfiança e as tomadas de consciência de que o modelo cartesiano que impregna o modelo positivista-normativista começa a esgotar as estratégias que moldaram um homem dolorosamente fraturado e permitiram imaginar o mundo pautado pela tirania da ordem. Posteriormente a Warat, seguiram-se vários autores a trabalhar com o tema, tais como Lenio Streck (2013), André Karan Trindade (2013; 2020; 2017;) Marta Gama (2019), Roberta Magalhães Gubert (2020), Alfredo Copetti Neto (2020), Nelson Camata Moreira (2015) e tantos outros.

Todos esses movimentos teóricos de aproximação entre literatura e direito, em suas mais distintas versões metodológicas, epistemológicas e 
estéticas, colocam-se exatamente na contramão de todo um cientificismo de caráter racionalista que contaminou o direito da modernidade com uma pretensão absoluta de ordem e certeza, distanciando-se completamente do mundo da vida, marcado pelas ambivalências, pelos estranhamentos, pelas diferenças, pelas incertezas e, certamente, por um permanente caos em sociedades cada vez mais complexas e cada vez mais difíceis de serem ordenadas pelo modelo de direito moderno. Partindo desta perspectiva crítica da relação entre literatura e direito, exploramos a obra de Galeano, buscando a identificação da ideia de diferença, categoria fundamental de novas concepções de direitos e de democracia, numa literatura com os pés absolutamente enraizados no chão da realidade mundana. Nossa perspectiva é a de buscarmos o direito e a filosofia na literatura.

\section{A DIFERENÇA COMO UMA CATEGORIA PÓS-MODERNA E DESCOLONIAL DE (DES)ORDENAÇÃO DO MUNDO}

A visão de mundo hegemonizada acerca da estruturação social na Idade Média caracterizou-se fundamentalmente pela compreensão de que a teia social tinha, formalmente, seus lugares marcados, o que evidenciava, nas relações sociais, a predominância principiológica da desigualdade. Esse paradigma tinha como motivo de fundo uma rede de privilégios estabelecida a partir de articulações fundadas no âmbito das relações privadas.

Com o advento das teorizações e institucionalizações políticas e jurídicas que caracterizaram os acontecimentos do liberalismo e do Iluminismo, bem como a sucessão dos eventos revolucionários que marcaram profundamente o século XVIII, o princípio da igualdade, consagrado no plano teórico e projetado nas construções institucionais que possibilitaram a ruptura com o paradigma medieval, tornou-se um elemento fulcral de todo o imaginário ocidental moderno. Para romper com a lógica privada medieval, sobre a qual se sustentava a institucionalização da desigualdade, a concretização, pelo menos normativa, da ideia de igualdade demandou a criação do espaço público para o desenvolvimento das relações sociais, como forma de 
eliminação de alguma parte dos privilégios próprios da Idade Média. Nesse sentido, a cidadania moderna só foi possível no âmbito público e foi um evento importante.

Aproximadamente duzentos e trinta anos foram percorridos na história da humanidade, com a hegemonia na cultura filosóficopolítico-jurídica ocidental da ideia de igualdade, sendo ela um dos principais elementos geradores das instituições políticas e jurídicas que orientaram e normatizaram as ações sociais ao longo desse lapso histórico. Entretanto, tal ideia sempre esteve muito mais vinculada aos cânones filosófico-políticos liberais do que a quaisquer outros. Tivemos, assim, ao longo da Modernidade, o predomínio de uma igualdade formal, quando se reconheceu muito mais a necessidade-possibilidade de "todos iguais" - uns mais iguais que outros - participarem igualitariamente da vida política. Também a formação dos chamados Estados-nação, a partir das aglutinações absolutistas que precederam os surgimentos dos modelos estatais que constituem o paradigma moderno, reforçou a ideia da necessidade de efetivação definitiva da igualdade formal, tendo como uma de suas consequências o sufocamento de culturas e grupos minoritários que habitavam partes dos territórios sobre os quais se consolidaram os Estados nacionais.

Não se pode esquecer, contudo, que os princípios do liberalismo e do Iluminismo, construídos como culturas políticas e jurídicas localizadas, e instrumentalizadas para solucionar problemas locais europeus relativos ao exercício do poder, desprenderam-se de seus microcosmos, e universalizaram-se a partir de uma construção mítica de neutralidade. Com isso, ocorreram historicamente reduções eurocêntricas de termos fundamentais como cultura, justiça, direito, cidadania e democracia, aparentemente inclusivas, mas que, na verdade, constituíram-se como altamente excludentes, especialmente ao estrangularem, e até mesmo liquidarem, outras culturas locais (SANTOS; LUCAS, 2019).

A cultura e as práticas políticas e jurídicas da Modernidade, fundamentalmente europeias, passaram praticamente incólumes em seus desideratos de homogeneização e de universalização por mais de dois séculos. Para tanto, a ficção igualitária cumpriu seu papel mítico de forma um tanto quanto eficiente. Mas a partir da década de sessenta 
do século passado, com a agudização de lutas políticas por diferentes grupos que compunham as sociedades multifacetadas de países do norte, passaram a ocorrer reações culturais, comportamentais, políticas e filosóficas voltadas a propor noções mais inclusivas e, simultaneamente, respeitadoras da diversidade, de concepções alternativas da dignidade humana que não mais se sustentavam sobre a ideia de igualdade formal, mas antes a criticavam a partir de novas visões de mundo, nas quais a diferença passou a ocupar um lugar destacado e exigir um sistema de proteção, inclusive jurídica. Nessa época, teve início uma grande revolução comportamental com o surgimento, dentre outros movimentos, do feminismo e dos movimentos civis em favor dos negros e homossexuais.

Assim, é possível afirmar que a partir da década de 60, inicialmente, sobretudo, nos Estados Unidos, um conjunto altamente heterogêneo de movimentos contestatórios, com um clímax no mítico “68”, empreendeu o caminho da institucionalização social, acadêmica, política e jurídica. As confluências programáticas desses novos movimentos sociais afro-americanos, indígenas, "chicanos", feministas, gays e lésbicas, "terceiro-mundistas", etc. -, se deram a conhecer a partir de então sob o ambíguo termo do "multiculturalismo" (DIETZ, 2012). 0 que todos esses movimentos tinham em comum era a necessidade de reconhecimento de suas diferenças socioculturais. Não desejavam - salvo em casos bem pontuais - que as especificidades de sua própria cultura suplantassem definitivamente o ideal nacional já estabelecido, ou mesmo que seus membros fossem considerados apartados do cenário cultural do Estadonação. Apenas almejavam ser reconhecidos dentro da nação à qual pertenciam, como portadores de características particulares que os diferenciavam da população ainda adstrita à ideia de cidadania nacional.

Se, por um lado, os acontecimentos sociais que marcaram os anos 60 do século passado podem, tranquilamente, ser considerados como movimentos sociais, dentro de uma clássica definição que os restringe conceitualmente como todo aquele ator coletivo que manifesta - com certa permanência no tempo e no espaço - uma capacidade de mobilização que se funda na elaboração de uma identidade própria e em formas de organização muito flexíveis e escassamente especializadas, com o objetivo de impactar no desenvolvimento da sociedade contemporânea e de suas 
instituições (MURO; CANTO, 1991), por outro, é preciso considerar a relevância do debate posto pela literatura surgida desde os anos 70, acerca do conceito de "novos movimentos sociais". Tentando resumir, numa ideia ou num mesmo denominador, em termos materiais, no que diz respeito à diversidade dos novos acontecimentos ou movimentos sociais, talvez o grande tema que possa ser comum a todos seja o problema da identidade sociocultural a partir de uma sintaxe da diferença. Assim, os objetivos primordiais dos novos movimentos sociais estão dirigidos para uma reorientação da esfera sociocultural, e não da economia ou do Estado (RASCHKE, 1988). Em certo sentido, pode-se dizer, como faz Fraser (2002), que as pautas de reconhecimento promoveram uma espécie de substituição da política pela cultura.

Esses novos movimentos sociais fundados na diferença e na diversidade constituem a marca de sociedades contemporâneas que cada vez mais se revelam como plurais, multifacetadas, multiculturais. Por certo que a pluralidade cultural é uma realidade e uma virtude das sociedades democráticas que deve ser estimulada. Por outro lado, o facilitado encontro das diferenças na sociedade global expôs, também, divergências e irritações que não favorecem o diálogo intercultural e que, não raras vezes, demarcam com agressividade o nível das oposições e afastamentos (OLIVÉ, 1999). Por isso, pode-se afirmar que as demandas por reconhecimento das identidades socioculturais desafiam duplamente os direitos humanos, pois ao mesmo tempo em que são requisitados para garantir os direitos de cada cultura particular, por outro, são considerados como exigências recíprocas de abrangência universalista, que não condicionam seus fundamentos e sua validade à nenhuma experiência cultural específica.

Esses grupos minoritários, muitas vezes tratados como anormais, como seres portadores de anomalias, monstros humanos ou indivíduos a serem corrigidos, utilizando a linguagem de Foucault (2001), não raro, são associados, tanto na literatura religiosa, pela sua diferença, pela sua discrepância, à simbologia figurativa do Diabo, quanto, porém de forma metafórica, em outros ramos literários. Nesse dualismo gnóstico proposto entre as figuras de Deus e Diabo, enquanto a igualdade, normalidade, concordância e maioria implicam, em sua invisibilidade, uma constante 
de expressão e conteúdo divino, o mundo da luz, da ordem e da certeza, de um destino de conforto sem derivações, que já está traçado aos que aderirem a sua versão de mundo, supondo um estado de poder e dominação, a diferença e todos os seus desdobramentos encarnam as anormalidades, anomalias, discrepâncias e minorias, com todas suas remissões musicais, literárias, linguísticas, étnicas, de gênero e sexualidade, enredam exatamente o contrário: alguém diabólico bem visível fora do sistema, uma variação contínua em estado de devir detonador de movimentos incontroláveis e de desterritorializações da média ou da maioria, o mundo do caos, da incerteza, das névoas e das águas tenebrosas (DELEUZE; GUATTARI, 2011).

Assim, a figura do Diabo, além de ser uma entidade mitológica, é, também, no campo literário, uma técnica discursiva de desqualificação da diferença, da anormalidade associada a estratégias de poder e processos de dominação, perspectiva que aparece denunciada, de forma insolente e quase anedótica, na literatura de Eduardo Galeano, um dos grandes escritores uruguaios contemporâneos que mescla crítica política com literatura. Mas antes apresentarmos os Diabos de Galeano, façamos um pequeno excurso histórico sobre as tão emblemáticas figuras de Satã, Asmodeu, Belzebu, Mefistófeles etc.

\section{UM APELO AO DIABO COMO O OUTRO NEGADO}

Pouquíssimas figuras são tão emblemáticas, ao longo da história, como foi e tem sido a representação do Diabo. Mas, afinal, quem é essa figura, colorida em múltiplos tons de cinza e negro por Eduardo Galeano? Em primeiro lugar, não era, segundo os textos sagrados da Bíblia, uma entidade de mil facetas, ou um conjunto de valores negativos, como nos conta o escritor uruguaio, mas personificadamente único, um anjo chamado Lúcifer que, seduzido narcisisticamente pela própria beleza, entendeu que deveria receber a mesma admiração que Deus, e em razão disso armou uma rebelião com aproximadamente um terço dos anjos que existiam nos céus (BÍBLIA SAGRADA, Ezequiel 28: 12-19, 1988). Esta descrição fantástica e sobrenatural do Diabo é própria da tradição 
judaico-cristã: "Vós tendes por pai ao Diabo, e quereis satisfazer os desejos de vosso Pai; ele foi homicida desde o princípio, e não se firmou na verdade, porque não há verdade nele, quando ele profere mentira, fala do que lhe é próprio, porque é mentiroso e pai da mentira" (BÍBLIA SAGRADA, João 8: 44, 1988, 1ª parte, p. 118).

A descrição oficial, ou melhor, a primeira versão publicada pela Igreja Católica da invenção do Diabo é posterior ao Concílio de Toledo, em 447 d.C., sendo ele, solene e burocraticamente descrito e difundido como a encarnação absoluta do mal. Nessas descrições constam a imagem de um ser medonho, muito grande e forte, de aparência escura, com chifres na cabeça, exatamente como o deus-touro Mithra, da qual a Igreja queria impedir a adoração. Nasce, com isso, o demônio na cultura cristã como a mais radical oposição a um projeto de mundo e de bem, cuja personificação plantou o medo nas pessoas que aderissem aos seus cultos, pois o castigo final seria a morte sem direito à vida eterna, seja em qual modalidade fosse (terrena ou espiritual).

Com outro olhar, podemos compreender o Diabo de uma forma mais terrena, histórica e estratégica, como uma farsa instrumentalmente criada para funcionar como ferramenta de repressão, opressão e imposição de certos valores propagados por indivíduos e grupos ligados a posições privilegiadas dentro de sistemas de dominação. A riqueza da descrição de Galeano reside no fato de condensar algumas associações históricas, que foram feitas por detentores do poder, entre a figura do Diabo e parcelas de indivíduos submetidas aos caprichos dos poderosos, e, por isso, perseguidos, presos e mortos por estarem associados a uma figura que personificava o mal. 0 Diabo, nessa perspectiva, expressa manifestamente as separações e segregações impostas pelos detentores do poder às minorias por eles indesejadas por dificultarem seus projetos de poder.

Na verdade, essas duas visões e compreensões do Diabo sempre se confundiram, pois as ações dirigidas aos seres diabólicos que se opunham aos projetos de poder terreno sempre tiveram como justificativas argumentos transcendentais, sobrenaturais, teológicos. Assim foi, por exemplo, com muçulmanos, mulheres, índios, judeus, negros e homossexuais que, de alguma forma, eram figuras que materializavam os pecados capitais que estruturaram fortemente a doutrina cristã da 
salvação, ou, em sentido contrário, da morte da alma pelo castigo em razão de condutas abomináveis, contrárias aos mandamentos de Deus.

Essas personificações de um Diabo transcendental, de uma figura espiritual do mal, também tiveram uma função histórica ligada à instalação de processos de dominação econômica ou de manutenção de algum modo de produção da riqueza, mediante a submissão ou exploração de alguns povos por outros. Isso aconteceu violentamente com os índios americanos, que foram vítimas de um genocídio sem comparação. A ocupação do território americano, de norte a sul, por colonizadores europeus, teve unicamente fins econômicos, mas em não raros momentos serviu-se de justificativas teológicas para motivar suas ações dominadoras e genocidas. Da mesma forma ocorreu com os negros africanos, os quais foram vítimas de um assalto existencial seguido de morte, em nome de um processo de descobrimento de um novo mundo econômico, cuja principal finalidade era saciar a sede de riqueza de Cortes violentas e decadentes que fizeram a sangrenta e não civilizada história medieval europeia. As missões católicas de conversão dos espíritos pagãos dos índios para a cristandade cumpriram, nesse aspecto, um forte papel colonizador, e a figura do Diabo foi icônica neste processo.

A Idade Média, na cultura ocidental, teve em seu centro imaginário e simbólico essa figura de Deus, como um ente pessoalizado, e, paralelamente, do lado oposto, como o próprio nome já sugere, os opositores, o Diabo e seus seguidores, os hereges, as bruxas, os alquimistas, os cientistas que negavam as teorias teocêntricas, os protestantes, em suma, todos os que divergiam de um sistema de verdade - e de poder - oficializado pela Igreja Católica. A fixação dessas imagens diabólicas pelas Inquisições contou não somente com um sistema de comunicação escrita e oral, mas lançou mão de estratégias iconográficas para a produção de imagens que desempenharam papéis importantíssimos, quer na expressão das oposições, quer na fixação hierática das cerimônias encenadas pelo tribunal.

Com a Modernidade não foi diferente, apenas trocaram-se as entidades. Substitui-se, parcialmente, o Deus personalizado medieval pela Deusa Razão, pela Deusa Igualdade, pela Deusa Liberdade e, também, foi substituído o Diabo, o ser medonho, muito grande e forte, de aparência escura, com chifres na cabeça, pelos Diabos modernos, o Diabo- 
Irracionalidade, o Diabo-Outro, o Diabo-Diferente, o Diabo-Minoria, os Diabos-Sexuais, os Diabos-Raciais, os Diabos de Galeano.

Se o Deus medieval, o ente onipresente e onisciente, sempre deteve as soluções para resolver os problemas do mundo, sempre possuiu as alternativas para um projeto de mundo que já estava predeterminado nas escrituras sagradas, desde a sua criação, também, de forma similar, as grandes narrativas modernas, os grandes projetos de desenvolvimento irrefreado e contínuos da humanidade, os deuses modernos do Iluminismo, do liberalismo ou do marxismo, não foram diferentes nesse aspecto. Eles possuíram e ainda possuem seu aspecto divino, determinista, pois se constituem como projetos totalizantes fechados e inevitáveis de mundo. E tudo o que a eles se oponha (Satanás, do latim, o que se opõe, o opositor, o que arma ciladas) deve ser demonizado, reprimido, criminalizado e, se possível, sem que haja um aviltamento muito sério do projeto, eliminado.

\section{OS DIABOS POLÍTICOS DE EDUARDO GALEANO E 0 CARÁTER EPISTEMOLÓGICO DA SUA LITERATURA PARA ESTUDO DA DIFERENÇA COMO CATEGORIA ADEQUADA À COMPLEXIDADE CONTEMPORÂNEA}

Em uma atitude literária socialmente engajada, o escritor uruguaio Eduardo Galeano (1940-2015), em algumas de suas obras, faz uma abordagem crítico-política acerca de alguns grupos historicamente oprimidos, notadamente por sua diferença em relação a estados de dominação e modelos de dominadores normalizados, buscando, com isso, uma intervenção no debate político acerca de grupos minoritários. Para isso, utiliza, de forma um tanto quanto insolente, quínica, a metáfora diabólica para trazer à consciência os textos ocultos que invisibilizam estes estados de poder e dominação que, em suas marchas históricas, oprimiram, calaram, puniram e eliminaram milhões e milhões de pessoas que pertenceram a alguns grupos não incluídos nas constantes do poder. Se alguma classificação epistemológica é possível de ser dada aos textos de Eduardo Galeano, a primeira que salta aos olhos é a de uma escritura 
pós-colonial, ou descolonial, por escancarar os processos de dominação etnocêntricos ou eurocêntricos, bem como por servir como instrumento de abertura a vozes oprimidas. Uma passagem inicial importante que traduz fielmente esta sua postura de resistência descolonial e crítica aparece em sua obra "O Livro dos Abraços", na qual o autor se refere, numa pequena prosa poética, aos "Ninguéns":

\section{Os ninguéns}

As pulgas sonham com comprar um cão, e os ninguéns com deixar a pobreza, que em algum dia mágico a sorte chova de repente, que chova a boa sorte em cântaros; mas a boa sorte não chove ontem, nem hoje, nem amanhã, nem nunca, nem uma chuvinha cai do céu da boa sorte, por mais que os ninguéns a chamem e mesmo que a mão esquerda coce, ou se levantem com o pé direito, ou comecem o ano mundano de vassoura.

Os ninguéns: os filhos de ninguém, os donos de nada.

Os ninguéns: os nenhuns, correndo soltos, morrendo a vida, fodidos e mal pagos.

Que não são, embora sejam.

Que não falam idiomas, mas dialetos.

Que não praticam religiões, mas superstições.

Que não fazem arte, mas artesanato.

Que não são seres humanos, mas recursos humanos.

Que não praticam cultura, mas folclore.

Que não têm cara, mas braços.

Que não têm nome, mas número.

Que não aparecem na história universal, mas nas páginas policiais da imprensa local.

Os ninguéns, que custam menos que as balas que os mata (2011, p. 71).

Com o mesmo enredamento político, em sua obra "Espelhos", Galeano trabalha, numa perspectiva literária histórica, alguns grupos de oprimidos e violentados e os respectivos sistemas de poder e dominação que os subjugaram, sob a figura metafórica do Diabo, utilizada em discursos e narrativas repressivas e coativas contra esses grupos. Os Diabos de Galeano são Diabos políticos, pois materializam simbolicamente um atrevimento audaz que denuncia estados de poder, 
de violência e dominação ao longo da história. Sua literatura grita e apela contra a diferença transformada em desigualdade.

\section{O Diabo é mulher}

Provavelmente a grande figura diabólica da história seja a mulher. Pintada no texto bíblico como a que pôs abaixo todo o Jardim do Éden por ter aceitado as tentações de provar o fruto proibido e burlado a vigilância do paraíso atribuída a Adão, as mulheres desde Eva encarnam boa parte da imoralidade, da luxúria e da perdição moral na visão de um sistema de dominação patriarcal. Diz Galeano (2008, p. 115) a respeito desse Diabo:

\section{O Diabo é mulher}

O livro Malleus Maleficarum, também chamado $O$ martelo das bruxas, recomendava o mais impiedoso exorcismo contra o demônio que tinha tetas e cabelos compridos.

Dois inquisidores alemães, Heinrich Kramer e Jakob Sprenger, escreveram, por encomenda do papa Inocêncio VIII, esse fundamento jurídico e teológico dos tribunais da Santa Inquisição.

Os autores demonstravam que as bruxas, harém de Satã, representavam as mulheres em estado natural, porque toda bruxaria provém da luxúria carnal, que nas mulheres é insaciável. E advertiam que esses seres de aspecto belo, contato fétido e mortal companhia encantavam os homens e os atraíam, silvos de serpente, caudas de escorpião, para aniquilá-los.

Esse tratado de criminologia aconselhava a submeter a tormento todas as suspeitas de bruxaria. Se confessavam, mereciam o fogo. Se não confessavam, também, porque só uma bruxa, fortalecida pelo amante, o Diabo, nas festas de feiticeiras, conseguia resistir a semelhante suplício sem abrir a boca.

O papa Honório III havia sentenciado:

- As mulheres não devem falar. Seus lábios carregam o estigma de Eva, que foi a perdição dos homens.

Oito séculos mais tarde, a Igreja Católica continua negando-lhes o púlpito. 0 mesmo pânico faz com que os fundamentalistas muçulmanos lhes mutilem o sexo e tapem seus rostos.

E o alívio pelo perigo conjurado move os judeus muito ortodoxos a começar o dia sussurrando:

- Obrigado, Senhor, por não me ter feito mulher. 
Essa situação de depreciação moral da mulher sempre andou de mãos dadas com a subjugação patriarcal econômica, a qual instaurou a inferioridade da mulher no grupo social, sendo sua capacidade de participar ativamente nas funções do grupo colocada em dúvida pelo poder masculino, que a relegou, então, ao espaço privado, passando a ser incluída subjetivamente como propriedade do homem. Dessa forma, as desigualdades de gênero vão sendo produzidas, consolidadas pelas relações sociais, políticas, econômicas e estabelecidas juridicamente, nos códigos de leis das sociedades de todos os tipos. Portanto, era possível inferiorizar, explorar e até mesmo matar a mulher com respaldo na lei, sem que houvesse qualquer punição legal para o ato, pois a mulher era uma res que compunha o patrimônio do homem. As mulheres humilhadas de Galeano, portanto, reclamam um estatuto, reclamam um lugar de reconhecimento e proteção. Sua diferença quer uma presença e potência para ser simplesmente o que é.

\section{O Diabo é muçulmano e judeu}

Outra importante situação de opressão da diferença descrita por Galeano, diz respeito à intolerância ética e religiosa. Muçulmanos e judeus foram, neste aspecto, particularmente alvos preferenciais, os primeiros, da Igreja Católica e, os segundos, de uma quantidade considerável de governos, especialmente ocidentais, mas também alguns das bandas orientais do mundo, que os responsabilizaram por inúmeros insucessos políticos, econômicos e sociais de suas próprias ações. Diz-nos Galeano (2008, p. 113) que:

\section{O Diabo é muçulmano}

Até Dante sabia que Maomé era terrorista. Não foi por acaso que o colocou num dos círculos do Inferno, condenado à pena de formão perpétuo. $E u$ o vi rachado, celebrou o poeta em A divina comédia, da barba até a parte inferior do ventre...

Vários papas haviam comprovado que as hordas muçulmanas, que atormentavam a Cristandade, não eram formadas por seres de carne e osso, mas eram um grande exército de demônios que tanto mais crescia quanto mais sofria os golpes das lanças, das espadas e dos arcabuzes. 
Lá pelo ano de 1564, o demonólogo Johan Wier tinha contado os Diabos que estavam trabalhando na terra, em tempo integral, pela perdição das almas humanas. Havia 7.409.127 que atuavam divididos em 79 legiões.

Muitas águas ferventes passaram, desde aquele recenseamento, por baixo das pontes do inferno. Quantos são, hoje em dia, os enviados do reino das trevas? As artes do teatro dificultam a contagem. Esses enganadores continuam usando turbantes, para ocultar seus chifres, e longas túnicas cobrem suas caudas de dragão, suas asas de morcego e a bomba que carregam debaixo do braço.

\section{O Diabo é judeu}

Hitler não inventou nada. Há dois mil anos que os judeus são os imperdoáveis assassinos de Jesus e os culpados de todas as culpas.

Como? Jesus era judeu? E também judeus eram os doze apóstolos e os quatro evangelistas? Como é que é? Não pode. As verdades reveladas estão além de qualquer dúvida: nas sinagogas o Diabo dá aula, e os judeus se dedicam desde sempre a profanar hóstias, a envenenar a água benta, a provocar falências e a semear pestes.

A Inglaterra os expulsou, sem deixar nem um, no ano de 1290, mas isso não impediu que Marlowe e Shakespeare, que talvez nunca tivessem visto um judeu na vida, criassem personagens obedientes à caricatura do parasita sanguessuga e usureiro avarento.

Acusados de servir ao Maligno, esses malditos andaram pelos séculos de expulsão em expulsão e de matança em matança. Depois da Inglaterra, foram sucessivamente expulsos da França, da Áustria, da Espanha, de Portugal, e de numerosas cidades suíças alemãs e italianas. Na Espanha, tinham vivido durante treze séculos. Levaram as chaves de suas casas. Há quem as tenha até hoje.

A colossal carniçaria organizada por Hitler foi o auge de uma longa história. A caça aos judeus sempre foi um esporte europeu.

Agora os palestinos, que jamais o praticaram, pagam a conta.

A manutenção de estados de poder e dominação sobre minorias e diferentes invariavelmente dependeu da existência de sistemas de verdade que tinham a finalidade de constituir o imaginário de maiorias acerca de todas as "anormalidades" e "monstruosidades" dos diferentes. A organização mais pródiga nesta estratégia foi a Igreja Católica, que instituiu, a partir de toda uma dogmática acerca do texto bíblico construída em seus concílios e suas doutrinas, um sistema policial e jurídico de perseguição aos que discordavam do autoritarismo 
hermenêutico católico. Para isto, foi instituído o crime de interpretação, mais conhecido como heresia, cuja pena era a morte numa fogueira. O início deste sistema de monopólio hermenêutico e consequente persecução de diferentes foi assim narrado por Galeano (2014, p. 171):

\section{Heresias}

No ano de 325, na cidade de Niceia, foi celebrado o primeiro concílio ecumênico da cristandade, convocado pelo imperador Constantino.

Durante os três meses que o concílio durou, trezentos bispos aprovaram alguns dogmas necessários na luta contra as heresias, e decidiram que a palavra heresia, do grego hairesis, que significava escolha, passava a significar erro.

Ou seja: comete erro quem escolhe livremente e desobedece aos donos da fé.

O Diabo de Galeano é diabo porque desafia a obediência incondicional e se instala como possibilidade de liberdade de escolha. Sua insolência perturba e desconserta, desgosta da ordem e flerta, o todo tempo, com a loucura, com a irracionalidade e a destemperança. Formas ainda vivas de diabolização do outro continuam o seu itinerário na sociedade contemporânea, notadamente nas narrativas religiosas que marcam suas diferentes formas de interdição do corpo, sexualidade e desejo.

\section{O Diabo é negro, é cigano e é índio}

A Europa, até o século XVIII, era uma região secundária do mundo. Quase nada produzia de tecnologia, mercadorias ou produtos que pudessem interessar ao resto do mundo. Para a consolidação do protagonismo europeu no novo sistema-mundo que se instalava, foi preciso subjugar alguns povos, especialmente índios e negros, utilizados como carvão humano para carburar o processo de produção da riqueza nas Américas. Para esse processo de dominação foi necessário criar um discurso desqualificador desses povos, e nessa narrativa o conceito de raça representou um papel categorial sem precedentes. Uma concepção de mundo delirante criada pelos europeus, dentro de uma lógica de auto ficção, autocontemplação e enclausuramento, na qual o mundo não pertence a todos em igualdade de condições. E nessa lógica, 
o negro, o índio e a ideia de raça constituem-se como designações pesadas, perturbadoras e desequilibradas, símbolos de intensidade crua e de repulsa. 0 racismo científico, tão propalado ao longo do século XIX, defendia que as diferentes raças não estão no mesmo estágio de desenvolvimento moral e intelectual, razão pela qual a mestiçagem era vista como uma forma de degeneração. Precisamos, portanto, separar as raças, segregá-las, colocá-las cada uma no seu devido lugar de importância. Afinal, como dizia Hegel (1999), o negro tem pouco a dizer, ele representa o homem natural, selvagem e indomável.

Consciente desse discurso de poder construído sobre à ideia de raça, Galeano expõe sua resistência ao racismo nas seguintes passagens:

\section{Diabo é negro}

Como a noite, como o pecado, o negro é inimigo da luz e da inocência.

Em seu célebre livro de viagens, Marco Polo evocou aos habitantes de Zanzibar: Tinham boca muito grande, lábios muito grossos e nariz de macaco. Andavam nus e eram totalmente negros, de maneira que quem os visse em qualquer região do mundo acreditaria que eram Diabos.

Três séculos depois, na Espanha, Lúcifer, pintado de negro, entrava em seu carro de fogo nos tablados de comédias e nos palcos das quermesses. Santa Teresa jamais conseguiu se livrar dele. Uma vez ficou parado ao seu lado, e era um negrinho muito abominável. Em outra ocasião, ela viu que uma grande chama vermelha saía do seu corpo negro, quando se sentou em cima do seu livro de orações e queimou suas rezas.

Na América, que tinha importado milhões de escravos, sabia-se que era Satã quem tocava os tambores nas plantações, convocando para a desobediência, e punha música e remelexos e tremores nos corpos dos seus filhos nascidos para pecar. E até Martin Fierro, gaúcho dos pampas, pobre e castigado, sentia-se bem comparando-se com os negros, que andavam mais fodidos que Ele: - Esses aí foram feitos pelo Diabo - dizia - para serem tição do inferno. (2008, p.116)

\section{Dia da diversidade cultural}

Em 1906, um pigmeu caçado na selva do Congo chegou ao zoológico do Bronx, em Nova York.

Foi chamado de Oto Benga, e foi exibido ao público, numa jaula, junto com um orangotango e quatro chipanzés. Os especialistas explicavam ao público que aquele humanoide podia ser o elo perdido, e para confirmar essa suspeita o mostravam brincando com seus irmãos peludos. 
Algum tempo depois, o pigmeu foi resgatado pela caridade cristã.

Fez-se o que foi possível, mas não teve jeito. Oto Benga se negava a ser salvo. Não falava, quebrava os pratos da mesa, batia em quem quisesse toca nele, era incapaz de fazer qualquer trabalho, ficava mudo no coro da igreja e mordia quem queria se fotografar com ele.

No final do inverno de 1916, depois de dez anos de domesticação, Oto Benga sentou-se na frente do fogo, queimou a roupa que era obrigado a vestir e apontou para o coração a pistola que havia roubado (2014, p. 167).

\section{Homem de cor}

Querido irmão branco;

Quando nasci, era negro.

Quando cresci, era negro.

Quando o sol bate, sou negro.

Quando estou doente, sou negro.

E enquanto isso, você:

Quando nasceu era rosado.

Quando cresceu foi branco.

Quando o sol bate, você é vermelho.

Quando sente frio é azul.

Quando sente medo, é verde.

Quando está doente, é amarelo.

Quando morrer, você será cinzento.

Então, qual de nós dois é um homem de cor?

(De Léopold Senghor, poeta do Senegal) (2014, p. 275).

\section{O Diabo é cigano}

Hitler achava que a praga cigana era uma ameaça, e não estava sozinho.

Fazia séculos que muitos achavam e continuavam achando que essa raça de origem obscura e escura cor leva o crime no sangue: sempre malditos, vagabundos sem outra casa que o caminho, violadores de donzelas e de fechaduras, mãos bruxas para o baralho e o punhal.

Numa só noite de agosto de 1944, 2.897 ciganos, mulheres, crianças, homens, viraram fumaça nas câmaras de gás de Auschwitz.

Um quarto dos ciganos da Europa foram aniquilados naqueles anos. Alguém perguntou por eles? (2008, p.116). 


\section{A pureza da raça}

Em 1924, Adolf Hitler ditou, na prisão, seu livro Mein Kampf. Num dia como hoje, transmitiu ao escriba seu ensinamento fundamental sobre a história da humanidade:

Todas as grandes culturas do passado sucumbiram apenas porque a raça originalmente criativa morreu por causa do envenenamento do sangue.

Catorze anos depois, Benito Mussolini proclamou, em seu Manifesto da raça: As características físicas e psicológicas europeias dos italianos não devem ser alteradas de forma alguma. Já é tempo de que os italianos se proclamem francamente racistas (2014, p. 273).

\section{O Diabo é índio}

Os conquistadores confirmaram que Satã, expulso da Europa, tinha encontrado refúgio nas ilhas e nas areias do mar do Caribe, beijadas pela sua boca flamejante.

Ali moravam seres bestiais que chamavam de brincadeira o pecado carnal e o praticavam sem horário nem contrato, ignoravam os dez mandamentos e os sete sacramentos e os sete pecados capitais, andavam pelados e tinham o costume de comer-se entre si.

A conquista da América foi uma longa e dura tarefa de exorcismo. Tão enraizado estava o Maligno nessas terras, que quando parecia que os índios se ajoelhavam devotamente diante da Virgem, estavam na realidade adorando a serpente que ela esmagava debaixo do pé; e quando beijavam a cruz estavam celebrando o encontro da chuva com a terra.

Os conquistadores cumpriram a missão de devolver a Deus o ouro, a prata e as muitas outras riquezas que o Diabo havia usurpado. Não foi fácil recuperar o butim. Ainda bem que, de vez em quando, recebiam uma ajudinha lá de cima. Quando o dono do Inferno preparou uma emboscada num desfiladeiro, para impedir a passagem dos espanhóis para o Morro Rico e Potosí, um arcanjo desceu das alturas e deu-lhe uma tremenda sova (2008, p.118).

\section{Os índios são pessoas}

Em 1537, o papa Paulo III ditou sua bula Sublimis Deus.

A bula entrou em choque contra aqueles que, desejando saciar sua cobiça, se atrevem a afirmar que os índios devem ser dirigidos à nossa obediência, como se fossem animais, com o pretexto de que ignoram a fé católica.

E em defesa dos aborígenes do Novo Mundo, estabeleceu que eles são verdadeiros homens, e como verdadeiros homens que são podem usar, possuir e 
gozar livre e licitamente de sua liberdade e do domínio de suas propriedades e não devem ser reduzidos à servidão.

Na América ninguém tomou conhecimento (2014, p. 182).

\section{A cultura do terror $/ 1$}

A sociedade antropológica de Paris os classificava como se fossem insetos: a cor da pele dos índios huitotos correspondia ao número 29 e 30 de sua escala cromática.

A Peruvian Amazon Company os caçava como se fossem feras: os índios huitotos erma mão-de-obra escrava que dava borracha ao mercado mundial. Quando os índios fugiam das plantações e a empresa os agarrava, eram envolvidos numa bandeira do \peru empapada em querosene e queimados vivos.

Michel Taussig estudou a cultura do terror que a civilização capitalista aplicava na selva amazônica no começo do século XX. A tortura não era um método para arrancar informações, mas uma cerimônia de confirmação do poder. Num longo e solene ritual, os índios rebeldes tinham suas línguas cortadas e depois eram torturados, para que falassem (2011, p. 140)

Os diabos de Galeano denunciam o projeto de europeização colonizadora que pretendia a universalização de suas verdades epistêmicas, políticas e econômicas. Uma região será desenvolvida ser for, necessariamente, um espelho do modo de ser da sociedade europeia: branca, cristã, heterossexual, burguesa. Galeano protesta, mais uma vez, contra essa homogeneização, contra o império do mesmo, e abre cancha para debater a importância do plural, do diverso, do diferente, da resistência.

\section{O Diabo é pobre}

Alguns fenômenos sociais são interpretados como parte de uma dinâmica natural no funcionamento de certos sistemas, sendo classificados, aparentemente, como normais, quando, na verdade, são processos profundamente violentos, por se constituírem como causalidades que interferem em processos éticos. Assim, por exemplo, uma crise econômica que leva à devastação, ao desemprego e à fome de milhões de pessoas é compreendida e explicada por capitalistas como 
uma consequência natural do funcionamento de um sistema no qual a livre iniciativa e a competitividade são peças fundantes da dinâmica econômica, e a pobreza e a fome uma consequência previsível e aceitável. Entretanto, a verdadeira faceta de uma crise econômica que leva a tão desastrosas consequências, porque atingem a própria vida humana de milhões e milhões de existência, é a faceta da violência.

Para justificar as mazelas do sistema capitalista, cuja origem está no escravagismo, processo histórico de produção da riqueza que permitiu uma acumulação sem a qual o capitalismo jamais teria acontecido, produziu-se um discurso de demonização, perseguição e punição dos pobres, cujo cerne situa-se na sua não contribuição ao desenvolvimento do sistema capitalista. Ou seja, sempre se buscou, no universo de produção da legitimidade capitalista, uma inversão da lógica discursiva em relação à pobreza: o pobre não é vítima do sistema, ele é um problema que precisa ser eliminado, pois não contribui com o seu desenvolvimento.

A perseguição e punição dos que não contribuem para o sistema de produção da riqueza sempre foi uma tônica nos discursos de justificação e de concretização das ações dos exploradores. Assim foi com os escravos que resistiam ao sistema escravagista; da mesma forma com os vadios, que na legislação penal brasileira eram considerados contraventores, situação que era estendida também aos mendigos; ou como na legislação civil são tratados os pródigos.

Esta condição da violência do fenômeno capitalista de produção da riqueza não passa despercebida para Galeano, que ironiza, pela figura diabólica, a condição inferiorizada, desqualificada dos pobres que é feita por um sistema de produção discursiva e de comunicação deste discurso que se projeta até mesmo ao sistema jurídico. Nas palavras de Galeano:

\section{O Diabo é pobre}

Nas cidades do nosso tempo, imensos cárceres que trancam os prisioneiros do medo, as fortalezas dizem ser casas e as armaduras simulam ser ternos. Estado de sítio. Não se distraia, não baixe a guarda, não confie. Os amos do mundo dão a voz de alarme. Eles que impunemente violam a natureza, sequestram países, roubam salários e assassinam multidões, nos advertem: cuidado. Os perigosos acossam, tocaiados nos subúrbios miseráveis, mordendo invejas, engolindo rancores. 
Os perigosos, os pobres: os pobres-Diabos, os mortos das guerras, os presos dos cárceres, os braços disponíveis, os braços descartáveis.

A fome que mata calando, mata os calados. Os especialistas, os pobrólogos, falam por eles. E nos contam em que não trabalham, o que não comem, o quanto não pensam, o quanto não medem, o que não têm, o que não pensam, o que não votam, em que não creem.

Só nos falta saber por que os pobres são pobres. Será porque sua fome nos alimenta e sua nudez nos veste?

\section{Combata a pobreza: maquie os números}

Durante uns bons anos, os grandes meios de desinformação celebraram, com tambores e clarins, as vitórias na guerra contra a pobreza. Ano após ano a pobreza batia em retirada.

Assim foi até o dia de hoje do ano de 2007. Então, os especialistas do Banco Mundial, com a colaboração do fundo Monetário Internacional e de alguns órgãos das Nações Unidas, atualizaram suas tabelas do poder de compra da população do mundo. Num relatório do International Comparision Program, que teve escassa ou nenhuma difusão, os especialistas corrigiram alguns dados das medições anteriores. Entre outros errinhos, descobriram que os pobres somavam quinhentos milhões a mais do que tinham sido registrados pelas estatísticas internacionais.

Eles, os pobres, já sabiam disso (2014, p. 394).

\section{Combata a pobreza: mate um pobre}

Em 1638, nasceu Luis XIV, rei da França, o Rei Sol.

0 Rei Sol viveu dedicado às gloriosas guerras contra seus vizinhos e ao cuidado de sua cacheada peruca, suas capas esplêndidas e seus sapatos de salto alto.

Sob seu reinado, duas sucessivas epidemias de fome mataram mais de dois milhões de franceses.

A cifra foi conhecida graças a Blaise pascal, que havia inventado, meio século antes, a calculadora mecânica. E a razão foi conhecida graças a Voltaire, que tempos depois escreveu:

- A boa política conhece este segredo: como fazer morrer de fome os que permitem que os demais vivam (2014, p. 285). 


\section{O Diabo é estrangeiro}

O acontecimento do Estado-nação constitui-se numa condição elementar no tocante à problematização teórica das migrações. É que com o surgimento do Estado-nação e suas estratégias políticas e jurídicas de homogeneização, a população passou a ser o objeto específico de governação e, logicamente, de teorização (COPETTI SANTOS, 2016). Alguns autores, como Botero (2012), foram fundamentais na construção de um discurso sobre a necessidade de controle da população. Desde Botero, os discursos de controle populacional, seja pelo controle da natalidade, seja pela da mobilidade, tornaram-se uma constante na Modernidade. 0 resultado disso foi uma polarização discursiva, política e jurídica entre sedentários e nômades, entre normais fixados, enraizados, e anormais em constante movimento.

A gestão dos corpos, a sua mobilidade, obedece, desde a modernidade, uma racionalidade ambivalente que tende a ser questionada pela dinâmica da vida contemporânea. 0 dentro e o fora do Estado estão cada vez mais fluídos e, justamente por isso, cada vez mais reforçados. 0 nacional afirma sua identidade, sua presença, numa relação ambivalente com o seu oposto, o estranho, o estrangeiro. É nesse sentido, diz Resta (1997), que a cidadania nacional une separando, inclui necessariamente excluindo. Se é brasileiro justamente por não ser outra coisa. A soberania dos Estados é o local e o poder dessa intervenção que permite entrar e que impede de sair. A Europa está vivendo isso de modo dramático: os seus limites territoriais são reforçados contra a invasão externa e o próprio conceito de Europa está cada vez mais definido pelo seu entorno.

A homogeneização promovida pelos Estados Nação foi brutal com a diversidade tanto dentro quanto fora dos seus limites. Ao reforçar a ideia de unidade, o Estado moderno institucionalizou a diversidade como um ameaça e algo a ser combatido. A pertença à comunidade é condição de possibilidade para acessar o seu estatuto jurídico-político. 0 estrangeiro, o imigrante, o refugiado, é o resultado objetivo da noção de identidade nacional como única possibilidade de acesso. Eles reforçam a ideia de pertença numa lógica ambivalente: conformam sua presença 
na relação com o seu oposto. 0 imigrante reforça a posição do cidadão nacional e vice-versa.

Na literatura galeana, duas passagens sobre os diferentes nômades:

\section{O Diabo é estrangeiro}

0 culpômetro indica que o imigrante vem roubar nosso emprego, e o perigômetro dispara a luz vermelha.

Se é pobre, jovem e não é branco, o intruso, o que veio de longe, está condenado à primeira vista por indigência, inclinação ao caos ou porte de pele. E em qualquer caso, se não é pobre, nem jovem, nem escuro, ainda assim é mal vindo, porque chega disposto a trabalhar o dobro a troco da metade.

0 pânico da perda do emprego é um dos medos mais poderosos entre todos os medos que nos governam nestes tempos de medo, e o imigrante está sempre à mão na hora de acusar os responsáveis pelo desemprego, pela queda do salário, pela insegurança pública e por outras desgraças terríveis. Antes, a Europa derramava sobre o sul do mundo soldados, presos e camponeses mortos de fome. Esses protagonistas das aventuras coloniais passaram à história como agentes viajantes de Deus. Era a Civilização lançada ao resgate da barbárie.

Agora a viagem é feita ao contrário. Os que chegam, ou tentam chegar, do sul para o norte, são protagonistas das desventuras coloniais, que passarão à história como mensageiros do Diabo. É a barbárie lançada ao ataque à Civilização.

\section{Imigrantes ilegais}

Em avião particular voaram até Monterrey.

E lá iniciaram, no ano de 2008, sua turnê triunfal. Foram declarados hóspedes de honra, e em nove carruagens passearam pelas avenidas.

Pareciam políticos triunfantes, mas não. Eram múmias. As múmias das vítimas da peste do cólera, que fazia mais de um século e meio tinha devastado a cidade de Guanajuato.

Onze mulheres, sete homens, cinco crianças e uma cabeça sem corpo, todos vestidos de festa, atravessaram fronteira. Em bora fossem múmias mexicanas, ninguém lhes pediu passaporte, nem foram acossadas pelos agentes de imigração.

E tranquilamente continuaram a viagem rumo a Los Angeles, Las Vegas e Chicago, onde desfilaram, ovacionadas, debaixo de arcos de flores (2014, p. 354). 
São diabólicos os imigrantes, os refugiados, os asilados, porque são portadores do medo, da pobreza, de culturas poucos elaboradas. De fato, não é tarefa das mais fáceis construir diálogos interculturais “[...] capazes de aceitar o imigrante e a sua diferença, sobretudo quando elas contrariam em muitos sentidos a ordem das coisas do lugar que os recebe" (LUCAS, 2016, p. 96). 0 imigrante materializa o resto, a sobra que quer um lugar no mundo civilizado. Portadores do crime, do terrorismo, da violência, ameaçam o emprego dos nacionais e a forma cultural de viver dos povos do norte. Aparecem para a história, diz Galeano, como mensageiros do Diabo. A alternativa encontrada pelas políticas nacionalistas cada vez mais extremas é atacar os imigrantes, demonizá-los, deixá-los para fora, impedir acessos. Fronteiras e muros são requisitados como uma forma garantir a pureza dos dentro contra os de fora. Não é sem razão que o presidente americano Trump tem bradado com potência que o seu governo acabará com a loteria da diversidade.

\section{O Diabo é homossexual}

Para que a violência do golpe, da violação, do acosso existam, é necessário que uma sociedade tenha, previamente, inferiorizado, discriminado, fragilizado ao grupo social - as mulheres, as crianças, os anciãos, os homossexuais etc. - que é o objeto da violência. Os processos de inferiorização, discriminação e fragilização operam como naturalizações; conformam em tal sentido invisíveis sociais. A rigor, não são invisíveis, mas tornam-se invisibilizados. 0 discurso médico, o discurso religioso fundamentalista, os discursos político e jurídico foram de transcendental importância para a inferiorização de sujeitos e de determinadas práticas sexuais consideradas desviantes. A homossexualidade, em particular, foi retratada, e ainda é para alguns conservadores, como uma violação da natureza. A sodomia, dizia o franciscano Bernardino de Siena (1380-1444), faz com que seus praticantes se inclinem para a cobiça, a inveja e a fadiga espiritual. Mesmo o mais inteligente jovem, uma vez corrompido pela sodomia, "se transforma numa criatura do Diabo", dizia ele (RICHARDS, 1993). Todo tipo de hostilidade foi e continua sendo praticada contra 
os homossexuais. Galeano tem clareza disso e faz de sua literatura uma denúncia irônica que nos responsabiliza. Resgatamos as seguintes três passagens de seus textos onde a diferença em relação à sexualidade, ao desejo constitui-se como objeto de sua resistência política:

\section{O Diabo é homossexual}

Na Europa do Renascimento, o fogo era o destino que mereciam os filhos do inferno, que do fogo tinham vindo. A Inglaterra castigava com morte horrorosa os que houvessem tido relações sexuais com animais, judeus ou pessoas de seu mesmo sexo.

Exceto no reino dos astecas e dos incas, os homossexuais eram livres na América. 0 conquistador Vasco Núñez de Balboa jogou aos cães famintos os índios que praticavam essa anormalidade com toda normalidade. Ele acreditava que a homossexualidade era contagiosa. Cinco séculos depois, ouvi o arcebispo de Montevidéu dizer a mesma coisa.

O historiador Richard Nixon sabia que esse vício era fatal para a Civilização:

- Vocês sabem o que aconteceu com os gregos? A homossexualidade os destruiu! Com certeza. Aristóteles era homo. Todos sabemos. E Sócrates também. E vocês sabem o que aconteceu com os romanos? Os últimos seis imperadores eram veados...

O civilizador Adolf Hitler havia adotado medidas drásticas para salvar a Alemanha desse perigo. Os degenerados culpados de aberrante delito contra a natureza foram obrigados a usar um triângulo cor-de-rosa. Quantos deles morreram nos campos de concentração? Jamais se soube.

No ano de 2001, o governo alemão resolveu retificar a exclusão dos homossexuais vítimas do Holocausto. Levou mais de meio século para corrigir a omissão.

\section{Para o manicômio já}

Os meros e outros peixes,

os delfins,

os cisnes, os flamingos, os albatrozes,

os pinguins,

as avestruzes,

os ursos coalas,

os orangotangos e outros macacos,

as mariposas e outros insetos 
e muito outros parentes nossos do reino animal têm relações homossexuais, fêmea com fêmea, macho com macho, por um tempinho ou para sempre. Ainda bem que não são pessoas: se salvaram do manicômio.

a obra de doenças mentais da Organização Mundial da Saúde (2014, p. 162).

A título de fechamento do texto, cabe destacar que a literatura de Eduardo Galeano encerra um alto potencial epistemológico quando tratamos de investigar a questão da diferença, especialmente daquilo que Boaventura de Sousa Santos (2009a) chama de as epistemologias do sul político global. Na obra de Galeano identificamos elementos pós/ decoloniais, elementos desconstrutivistas de verdades estabelecidas por tradições de pesquisa e pensamento, componentes feministas, antirracistas, de teoria queer, enfim, epistemologias de vencidos.

Estando a obra de Galeano numa zona de interseção entre a ciência histórica e a arte literária, não há como negar a sua centralidade dentro das humanidades, e o seu estudo apresenta, quando relacionado ao Direito, até mesmo um caráter aplicado, pois denota a dependência constitutiva da literatura em relação a alguma espécie de fazer. Provavelmente, a grande função do estudo de textos literários como os de Galeano, associando-os a outras áreas do conhecimento epistemologicamente validados, seja a função crítica que a literatura possa exercer sobre categorias conceituais destas outras áreas. Este é o seu fim prático; este é o seu caráter aplicado.

\section{CONSIDERAÇÕES FINAIS}

Eduardo Galeano ficou famoso na década de 1970, mais precisamente em 1971, com o lançamento de "As Veias Abertas da América Latina", um texto clássico para os seguidores de filosofias anticapitalistas e antiimperialistas na América Latina durante os últimos 50 anos. 0 livro conta a história da América Latina exaltando a violência do processo de colonização europeia, e, posteriormente, da exploração e interferência norte-americana. A obra é, sem dúvida, uma literatura descolonial. Tal foi o impacto do livro que Galeano é comumente associado a ele, mas sempre que perguntado sobre se este era o seu grande livro, recusava-se 
a corroborar esta afirmação, pois entendia ser escritor de outras obras, e não de apenas uma.

Escritor de outras obras, sem dúvida alguma Galeano foi, e algumas delas até mesmo com mais sofisticação literária que a própria "Veias Abertas". Entretanto, se há algo que "Veias Abertas" marcou na vida literária de Galeano, este algo é a sua escritura engajada politicamente, estilo que jamais foi abandonado pelo escritor uruguaio, e que se refinou na denúncia contra os estados de poder e dominação contra os grupos de oprimidos, conforme se revelou em outros livros como "O livro dos abraços" e "Os filhos dos dias".

Na obra de Galeano "Espelhos", utilizada como base de nosso trabalho, cujo objetivo principal foi buscar em sua literatura elementos ligados à ideia da diferença, a associação da figura do Diabo com grupos minoritários - no sentido atribuído a este termo por Deleuze e Guattari - tem uma função política de afrouxar os limites dos campos de poder e dominação da Modernidade.Se a posição e a funcionalidade dadas à figura diabólica nos discursos de dominação foi desqualificar, inferiorizar minorias indesejadas e passíveis de controle e punição, na obra de Galeano, pela insolência quínica com que é tratada o Diabo, a função é invertida: ela traduz tentativas de afrouxamento de limites impostos às minorias pelas maiorias. Esta função pode ser trazida para as projeções emancipatórias que podemos fazer dos sistemas jurídicos constitucionais de nosso tempo, os quais possuem uma verdadeira potencialidade terapêutica contra possíveis abusos de uma maioria constante endeusificada.

Essa concepção contramajoritária das Constituições surge exatamente no mesmo momento em que movimentos sociais passaram a questionar alguns modos de ser dominantes que abafaram historicamente percursos morais concretos de determinados grupos sociais. Isso se deu inicialmente nos Estados Unidos com os movimentos de luta pelos direitos civis, mais notadamente com a efetividade da organização do movimento negro americano. Daí, alastrou-se para uma série de outros grupos minoritários, ou não minoritários, mas com alta vulnerabilidade social. Por outro caminho, também se consolidou no campo da filosofia, da ciência política, da sociologia e da antropologia um conjunto mais sólido 
de teorizações acerca das temáticas da identidade, da autenticidade, da diferença e do reconhecimento.

Essas duas dinâmicas - pragmático-política e teórica -, ao estabelecerem imbricações e convergências mútuas desde a sexta década do século passado, propiciaram uma projeção mais efetiva, no campo jurídico, de demandas pela tutela desses grupos, seja pelo estabelecimento de barreiras a possíveis violações, seja pelo estímulo de políticas públicas voltadas ao reconhecimento de diferenças e à equalização de disparates históricos perpetrados por maiorias.

0 que estamos vendo, com as tentativas de afrouxamento de limites majoritários por minorias, é o arrostamento das maiorias consideradas em seu aspecto de constância, de expressão e de conteúdo; a corrosão de estados de poder e de dominação, dos limites da própria constante, de um padrão abstrato que se invisibiliza em sua hegemonia e que, como Deus, não aparece em formato histórico algum, sendo, paradoxalmente, alguém por ser Ninguém.

Este trabalho é apenas uma tentativa de agenciamentos, a partir de alguns bulbos densificados pela noção de minoria, em suas vontades de poder rizomáticas de estabelecer linhas de segmentação e de fuga, movimentos de desterritorialização e desestratificação em relação a algumas superfícies de registro e produção que caracterizaram uma Modernidade, paradoxalmente, ao mesmo tempo, libertadora e opressora. As noções de minoria e diferença, em suas remissões jurídicas e políticas, em seus estados de etnia, língua e sexo, com suas territorialidades de gueto, são a nota tônica de uma composição policromática em tom menor, fazendo aqui uma remessa musical, campo que também absorve a noção de minoria.

Se alguma pretensão universalista pode existir em nosso texto, é a de estabelecimento de uma figura universal da consciência minoritária, como devir criativo de todo o mundo, em variação contínua, como uma amplitude que não cessa de transpor, por excesso e por falta, o limiar representativo do padrão divino majoritário. Erigindo a figura diabólica de uma consciência minoritária, dirigimo-nos a potências de devir que pertencem a um outro domínio, que não o do poder e da dominação por 
uma constante divinizada, mas a um devir minoritário diabólico, opositor, constituinte da autonomia de todos os Diabos de Galeano.

\section{REFERÊNCIAS}

BÍBLIA SAGRADA. 28. reimp. Rio de Janeiro: Imprensa Bíblica Brasileira, 1988.

BINDER, Guyora e WEISBERG, Robert. Literary criticisms of law. New Jersey: Princeton University Press, 2000.

BOTERO, Giovani. On the cause of the greatness of cities. Toronto: University of Toronto Press, 2012.

BRUNER, Jerome. Fabricando histórias: direito, literatura, vida. São Paulo: Letra e Voz, 2014.

CARDOZO, Benjamin . Law and Literature. Yale law journal, n. 48, 1938, pp. 489-507.

CARDOZO, Benjamin. The nature of judicial process. New Haven: Yale University Press, 1991.

COPETTI SANTOS, André Leonardo. Reterritorializando saberes sobre as mobilidades humanas contemporâneas. In: JULIOS-CAMyoyPUZANO, Alfonso de (et al). Direitos humanos, migração e diversidade: dilemas da vida em movimento na sociedade contemporânea. Ijuí: Ed. Unijuí, 2016, pp. 63-92.

DELEUZE, Giles; GUATTARI, Félix. Mil platôs. Rio de Janeiro: Editora 34, 2011.

DIETZ, Gunther. Multiculturalismo, interculturalidad y diversidad en educación. Una aproximación antropológica. México D. F.: Fondo de Cultura Económica, 2012.

DWORKIN, Ronald. Uma questão de princípio. São Paulo: Martins Fontes, 2001.

FISH, Stanley. Don't know much about the middle ages: posner on law and literature. Yale Law Review, n. 97, 1987, pp. 777-793. 
FISH, Stanley. Don't Know Much About the Middle Ages: Posner on Law and Literature. Yale Law Review, n. 97, 1987, pp. 777-793.

FISS, Owen. The Bureaucratization of the Judiciary. Yale Law Journal, n. 92, 1982, pp. 1442-1968.

FOUCAULT, Michel. Os anormais. São Paulo: Martins Fontes, 2001.

FRASER, Nancy. A justiça social na globalização: redistribuição, reconhecimento e participação. In: Revista Crítica de Ciências Sociais, nº 63, out. 2002.

GALEANO, Eduardo. As veias abertas da América Latina. Rio de Janeiro: Paz e Terra. 1978.

GALEANO, Eduardo. Espelhos. Uma história quase universal. Tradução de Eric Nepomuceno. Porto Alegre: L\&PM Editores, 2008.

GALEANO, Eduardo. Mulheres. Porto Alegre: LPM, 1997.

GALEANO, Eduardo. 0 livro dos abraços. Porto Alegre: LPM, 2011.

GALEANO, Eduardo. Os filhos dos dias. 3. ed. Porto Alegre: LPM, 2014.

GAMA, Marta. Entrelugares entre direito e arte: experiência artística e criação na formação do jurista. Fortaleza: EdUECE, 2019.

HEGEL, Friedrich. Enciclopédia das ciências filosóficas em epítome. Lisboa: Edições 70, 1999.

LEVINSO, Cinthia; LEVINSON, Sanford; SHEWD, Ally. Fault lines in the Constitution: The graphic novel. New York: First Second, 2019.

LUCAS, Doglas Cesar. Direitos humanos, diversidade cultural e imigração: a ambivalência das narrativa modernas e a necessidade de um paradigma de responsabilidades comuns. In: JULIOS-CAMPUZANO, Alfonso de (et al). Direitos humanos, migração e diversidade: dilemas da vida em movimento na sociedade contemporânea. Ijuí: Ed. Unijuí, 2016, pp. 93-154. 
MORAWETZ, Thomas. Literature and Law. Riverwoods, IL: Aspen publishers, 2007.

MOREIRA, Nelson Camatta e OLIVEIRA, Juliana Ferrari de. Direito e literatura e os múltiplos horizontes de compreensão pela arte. Ijui: Unijui, 2015.

MURO, Víctor Gabriel; CANTO CHAC, Manuel. Introducción. In: MURO, Víctor Gabriel; CANTO CHAC, Manuel (coord.) El estúdio de los movimentos sociales: teoria y método. Zamora, Mich: El Colegio de Michoacán, pp. 9-18, 1991.

NUSSBAUM, Martha. Justiça Poética: la imaginación literaria y la vida pública. Barcelona: Andres Bello, 1997.

OLIVÉ, León. Multiculturalismo y pluralismo. Paidós: México, 1999.

OST, François. Contar a lei: as fontes do imaginário jurídico. São Leopoldo: Unisinos, 2004

POSNER, Richard. Law and Literature: a relation reargued. Chicago: University of Chicago Law School, 1986.

POSNER, Richard. Cardozo- a Study on Reputation. Chicago: The University of Chicago Press, 1990.

POSNER, Richard. The Little Book of Plagiarism. New York: Pantheon, 2007.

RASCHKE, J. Sobre el concepto de movimiento social. Zona Abierta, n. 69, p. 121-134.

RESTA, Eligio. Le stelle e le masserizie. Paradigmi dell'osservatore: Roma-Bari, 1997.

RICHARDS, Jeffrey. Sexo, desvio e danação. As Minorias na Idade Média. Rio de Janeiro: Jorge Zahar,1993.

ROTMAN DE MIRANDA, Martha S. Filo-Arte. Buenos Aires: Dunken, 2010. 
SANTOS, André Leonardo Copetti: LUCAS, Doglas Cesar. A (in) diferença no direito. Minorias, diversidade e direitos humanos. Porto Alegre: Livraria do advogado, 2019.

SANTOS, Boaventura de Sousa. Sociologia jurídica crítica. Madrid: Trotta, 2009.

SANTOS, Boaventura de Sousa; MENESES, Maria Paula (orgs). As epistemologias do Sul. Coimbra: Almedina, 2009.

SARAMAGO, J. 0 evangelho segundo Jesus Cristo. São Paulo: Cia. das Letras, 1991.

STRECK, Lenio Luiz; TRINDADE, André Karan. (Org.). Direito e literatura: Da realidade da ficção à ficção da realidade. São Paulo: Atlas, 2013.

TRINDADE, André Karam; GUBERT, Roberta; COPETTI NETO, Alfredo (Org.). Direito e Literatura. Porto Alegre. Sergio Fabris Editor, 2020.

TRINDADE, André Karan; BERNSTS, Luísa Giuliani. O estudo de direito e literatura no Brasil. Surgimento, evolução e expansão. Anamorphosis. Revista Internacional de Direito e Literatura. v. 3, n.1, jan-jun, 2017.

WARAT, Luis Alberto. A Ciência jurídica e seus dois maridos. Santa Cruz do Sul: EDUNISC, 1985.

WEISBERG, Richard. Coming of Some More: "Law and Literature" Beyond the Cradle. Nova Law Review, n. 13, 1988, pp. 107-124.

WEISBERG, Richard. Law, Literature and Cardozo's Judicial Poetics. Cardozo Law Review, n. 1, 1979, pp. 283-342.

Recebido em: 31-8-2019

Aprovado em: 16-12-2019 


\section{Doglas Cesar Lucas}

Pós-Doutor em Direito pela Università Degli Studi di Roma Ter; doutor em Direito pela UNISINOS; professor dos Cursos de Graduação, Mestrado e Doutorado em Direito da Universidade Regional do Noroeste do Estado do Rio Grande do Sul - UNIJUÍ/RS e do Curso de Graduação em Direito da Faculdade CNEC Santo Ângelo; professor colaborador do Mestrado e Doutorado em Direito da Uri Santo Ângelo; editor-chefe da Revista Direitos Humanos e Democracia (B1). Avaliador do Inep/Mec. E-mail: doglasl@unijui.edu.br

\section{André Leonardo Copetti Santos}

Pós-Doutor pela Universidade do Vale do Rio dos Sinos (UNISINOS) e pósdoutorando pela Universidade de Santiago do Chile (USACH); mestre (1999) e doutor (2004) em Direito pela UNISINOS; professor do corpo permanente do Programa de Pós-Graduação em Direito da UNIJUí/RS e do Programa de Pós-Graduação em Direito da URI, Santo Ângelo/RS; coordenador executivo do PPGD/URISAN; editor da Revista Científica Direitos Culturais. Membro fundador da Casa Warat Buenos Aires e da Editora Casa Warat; advogado. E-mail: andre. co.petti@hotmail.com

Universidade Regional do Noroeste do Estado do Rio Grande do Sul (UNIJUÍ) - RS R. do Comércio, 3000 - Universitário, Ijuí - RS, 98700-000 